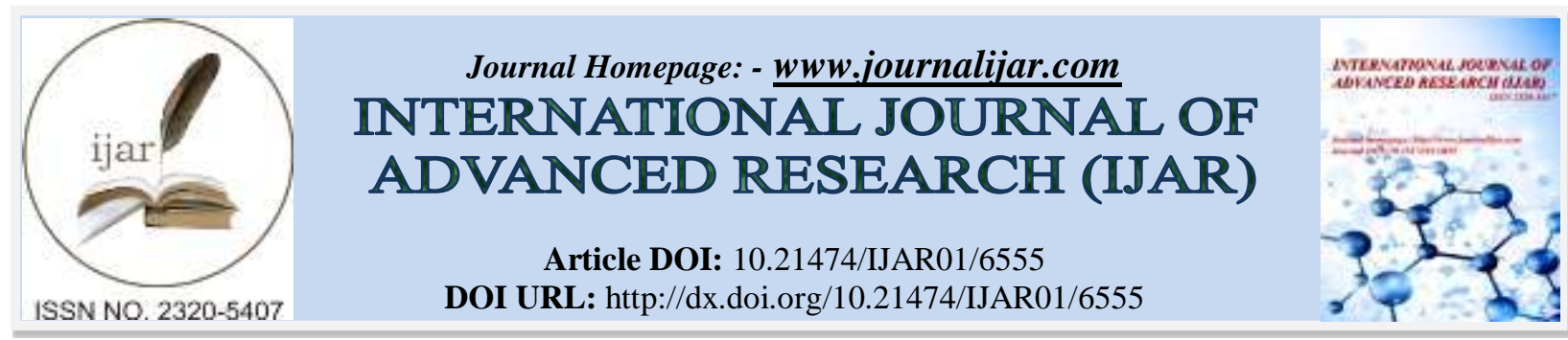

RESEARCH ARTICLE

\title{
STUDY OF MASLOW NEEDS HIERARCHIES IN HIGHER EDUCATION TEACHERS.
}

\author{
Betty Sarabia Alcocer ${ }^{1}$, Luis Alberto Núñez Oreza ${ }^{2}$, Betty Mónica Velázquez Sarabia ${ }^{3}$, Paulino Tamay \\ Segovia $^{2}$, Selene Blum Domínguez ${ }^{2}$, Patricia Margarita Garma Quen ${ }^{4}$, Rafael Manuel de Jesús Mex Álvarez ${ }^{4}$, \\ and Wilberth Manuel Camas Zetina 5 . \\ 1. Faculty of Medicine of the Autonomous University of Campeche. \\ 2. Center for Biomedical Research. Autonomous University of Campeche. \\ 3. Doctor Surgeon graduated from the Faculty of Medicine of the U.A.C \\ 4. Faculty of Biological Chemistry. \\ 5. Student of the Licentiate Medical Surgeon.
}

\section{Manuscript Info}

Manuscript History

Received: 16 December 2017

Final Accepted: 18 January 2018

Published: February 2018
Abstract

Antibiotic sensitivity revealed that all isolates were fully susceptible to enerofloxacin, ciprofloxacin, while all isolates were fully resistant to penicillin. E. coli serogrouped isolates were subjected to PCR for detection of Stx 1 and Stx2 genes. 3 out of 7 serogrouped isolates $(42.85 \%)$ were carried Stx2 gene (O55 and O27 from contact human and 086 from mastitic milk) while Stx 1 gene was not detected. phylogenetic analysis for the sequence data of the Sxt2 gene of E. coli serogroupes revealed that $S x t 2$ gene isolated from mastitic milk of cattle is closely identical (100\% identity) to $S x t 2$ gene isolated from contact human. In Conclusion, isolation of STEC from cattle might have potential pathogenicity for human. So that contact human should use sound hygienic measures during milking and management of these animals to avoid zoonotic infection.

Copy Right, IJAR, 2018,. All rights reserved.

\section{Introduction:-}

In interpersonal relationships, individuals find the great probability of satisfying all their needs, and being able to develop their potential, these relationships are vital and important in daily life, as well as for human development, through them we can know and understand the processes of life and make decisions to prioritize our basic needs. In this sense we can affirm that healthy interpersonal relationships form self-regulated individuals with attributes that are enriched as they reach goals proposed in life in a social environment where interaction with people creates conditions for achieve human development and well-being.

By nature, people during their life, seek to meet their physiological, economic and emotional needs, which is why various theories that facilitate this search have arisen. That is why the present study will take as reference the Theory of Basic Needs of Abraham Maslow to analyze what are the motivations that allow to hierarchize the needs of teachers at the current higher level, in which there is talk of a deterioration of interpersonal relationships.

\section{Importance:-}

The objective of this study is to analyze the level of Maslow's basic needs according to the order of importance assigned to it by six higher-level teachers who attend the second semester of the Doctoral Degree in Humanistic 
Education. The intention is to know what the needs are. They have already met at this moment in life and identify the one that is still in their search to feel like a self-regulated person. The results of the diagnosis will also be very useful for a space of reflection on how life is perceived from a human approach.

\section{Keywords:-}

Hierarchy of Maslow's needs, teachers, higher level.

\section{General Purpose:-}

Analyze Maslow's hierarchy of needs in higher-level teachers.

\section{Specific Objectives:-}

1. Interpret the results of the Maslow's Hierarchy of Needs Scale applied to higher-level teachers.

2. Compare the percentages of the Maslow Needs hierarchy by gender, age range, by areas of Higher Education (Social Sciences, Health Sciences and Exact Sciences).

3. Define the general percentage and the percentage prevalence of the Maslow Needs hierarchy.

\section{Methodology:-}

The present investigation is of a descriptive, quantitative, observational and transversal type, whose objective is to measure and hierarchize the basic needs of teachers at a higher level.

The methodological instrument for the collection of primary data consisted in the application of the survey of Maslow's Needs Hierarchies, composed of two sections, the first consisting of 25 items, to measure the question ¿What are you looking for in life ?, and the second that allowed to hierarchize Maslow's basic needs. For the measurement the Likert scale was used with the following values: 1. strongly disagree (TD), 2. Disagree (D), 3. Neither agreement nor disagreement (AD), 4. Agree (A) and 5 Totally in agreement (TA). Appendix 1

A sample of 6 higher level teachers from different areas of knowledge was chosen in a universe of 14 students from the E-25 group who are studying the second semester of the Doctoral Degree in Humanistic Education, at the Humanist Institute of Higher Studies in Sinaloa, Campeche headquarters.

For the processing and statistical analysis of the data obtained in the survey, the Microsoft Excel program version 15.22 (2016) was used.

\section{Context And Characteristics Of The Subjects:-}

During the life cycle, people seek to satisfy needs that arise at different times in their lives, each covered need leads them to consider another that provides a better quality of life and social position. This behavior is what Maslow calls the hierarchy of needs, is a concept proposed in his theory of personality that shows a series of needs that concern every individual and that are organized in a structural way (like a pyramid), according to a biological determination caused by the genetic constitution of the individual. In the lowest part of the structure, the most priority needs are located and in the lower part, the lowest priority. (López, C.2001).

Maslow points out that the structure of the needs of individuals already has an order by nature, and only should be identified at what level people are. For the case of this study, it is important to note that the study subjects are people of both sexes, with a profession (Economics, Social Work, Psychology, Engineering, Nursing and Medicine) and they have master's degree, they work as teachers at a higher level in various educational institutions at the state and federal level. Geolocated in the city of San Francisco de Campeche, Mexico; with 4 to 25 years career. They are currently $\mathrm{PhD}$ students, whose average age is 46 years old, obtained from the age range of 29 to 58 years, and a prevalence of single marital status. The data described are presented below in Table 01.

\begin{tabular}{|c|c|c|c|c|c|c|}
\hline \multicolumn{2}{|l|}{ Table 01:- General characteristics of the study subjects. } \\
\hline Subject & Gender & $\begin{array}{c}\text { Higher Education } \\
\text { Area }\end{array}$ & Profession & $\begin{array}{c}\text { Institution where he or she } \\
\text { works }\end{array}$ & $\begin{array}{c}\text { Marital } \\
\text { Status }\end{array}$ & Age \\
\hline 1 & M & Social Sciences & Psychology & $\begin{array}{c}\text { Universidad Autónoma de } \\
\text { Campeche }\end{array}$ & Single & 29 \\
\hline 2 & M & exact Sciences & Biochemistry & Instituto Tecnológico de & Single & 32 \\
\hline
\end{tabular}




\begin{tabular}{|c|c|c|c|c|c|c|}
\hline & & & Campeche & & \\
\hline 3 & F & Social Sciences & Economy & $\begin{array}{c}\text { Universidad Autónoma de } \\
\text { Campeche }\end{array}$ & Single & 53 \\
\hline 4 & F & Social Sciences & Social Work & Instituto Campechano & Married & 52 \\
\hline 5 & F & Health Sciences & Medicine & $\begin{array}{c}\text { Universidad Autónoma de } \\
\text { Campeche }\end{array}$ & Married & 53 \\
\hline 6 & F & Health Sciences & Nursing & $\begin{array}{c}\text { Universidad Autónoma de } \\
\text { Campeche }\end{array}$ & Single & 58 \\
\hline
\end{tabular}

Source: Collegial work. Campeche. 2017

According to this structure, when the needs of a certain level are met, the individual does not become apathetic, but rather finds the next level of satisfaction in the needs of the next level. And this is where the theory fails, since the human being always wants more and this is within his nature. When a man suffers from hunger, the most normal thing is that he takes great risks to obtain food. Once he has managed to feed himself and knows that he will not die of hunger, he will worry about being safe, feeling secure, he will want to find a love, etc. (López, C.2001). That is, not necessarily once a need is reached, it ceases to be a priority for people, rather once it is covered, it is motivated to seek other satisfactions.

\section{Findings:-}

The results of the diagnosis of the hierarchy of Maslow's basic needs. In the higher level, teachers showed that, at this moment of life, the search for the need for self-realization is the most important with 22 points, followed by security and social, which reached 20 points each and those of less search were the physiological and estimated, with 19 points each.

Charts 1 and 2 present the average percentages and total percentages by type of need, in them it is identified that among the five basic needs raised by Maslow: physiological, safety, social, esteem and self-realization, the latter has the highest average with the $22 \%$

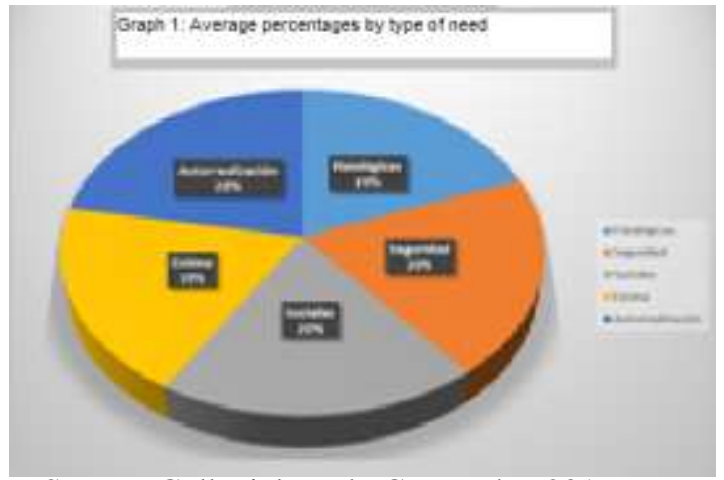

Source: Collegial work. Campeche. 2017

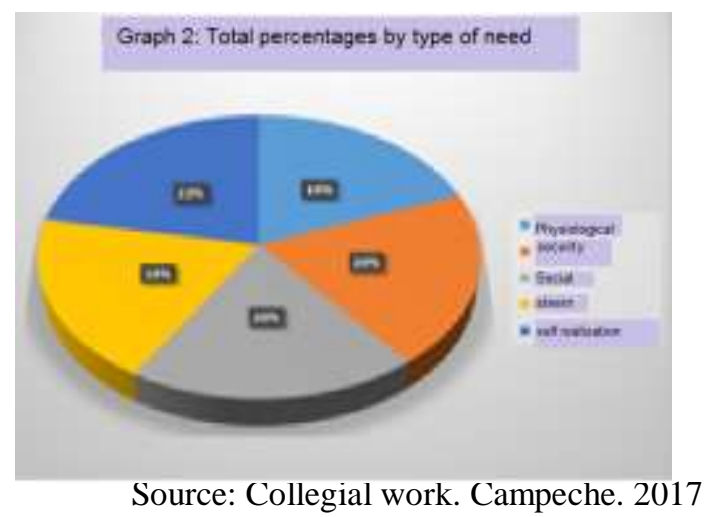

This result infers that in the case of a group of doctoral students and considering that education is an aspiration, even more so in higher education teachers, the prevalence of the need for self-realization among the five basic needs raised by Maslow is a result of having covered relatively the levels of needs prior to self-realization Seen from a gender perspective. It was found that in the physiological, social and esteem categories, women assigned greater value, which means that the female gender is constantly in the search for affection and inclusion. In relation to men the priority is to achieve, the level of security that is to consider the provider of your home, the concern focuses on the stability of a job and a good working environment and finally found that both sexes are motivated to achieve self-realization is more desired by higher-level teachers. Therefore, it is concluded that there is little significant difference between Maslow's needs between the two genders since he found the prevalence of the search for selfrealization. The above is shown in Figure 3. 


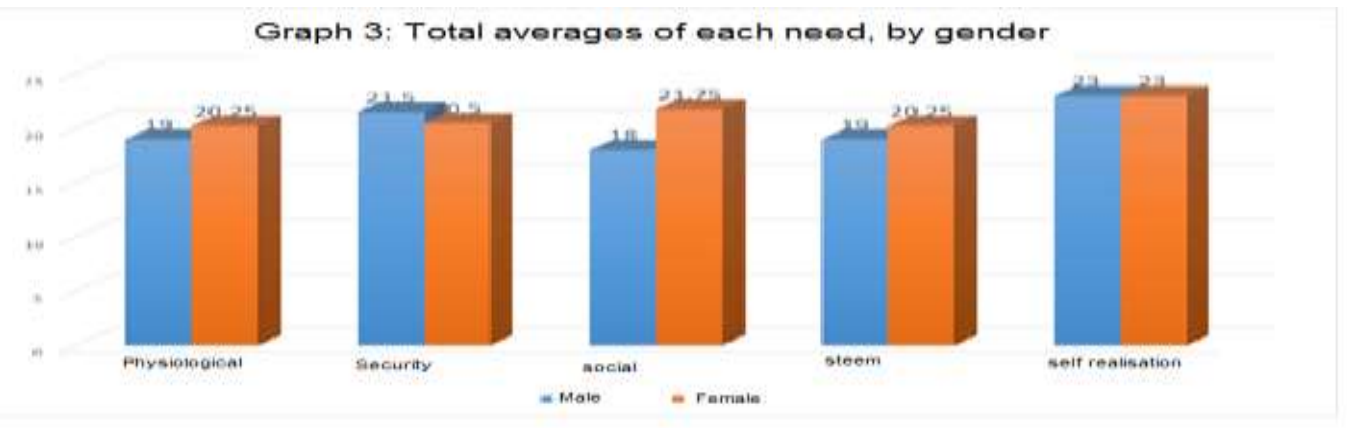

Source: Collegial work. Campeche. 2017

It is important to mention that the gender condition can be linked to the basic needs of people, considering the results in the present study and taking as reference Figure 4, it is deduced that in the masculine gender the need for safety prevails and in the feminine, the social

\section{Graph 4: Percentage of the hierarchy of needs, by gender}

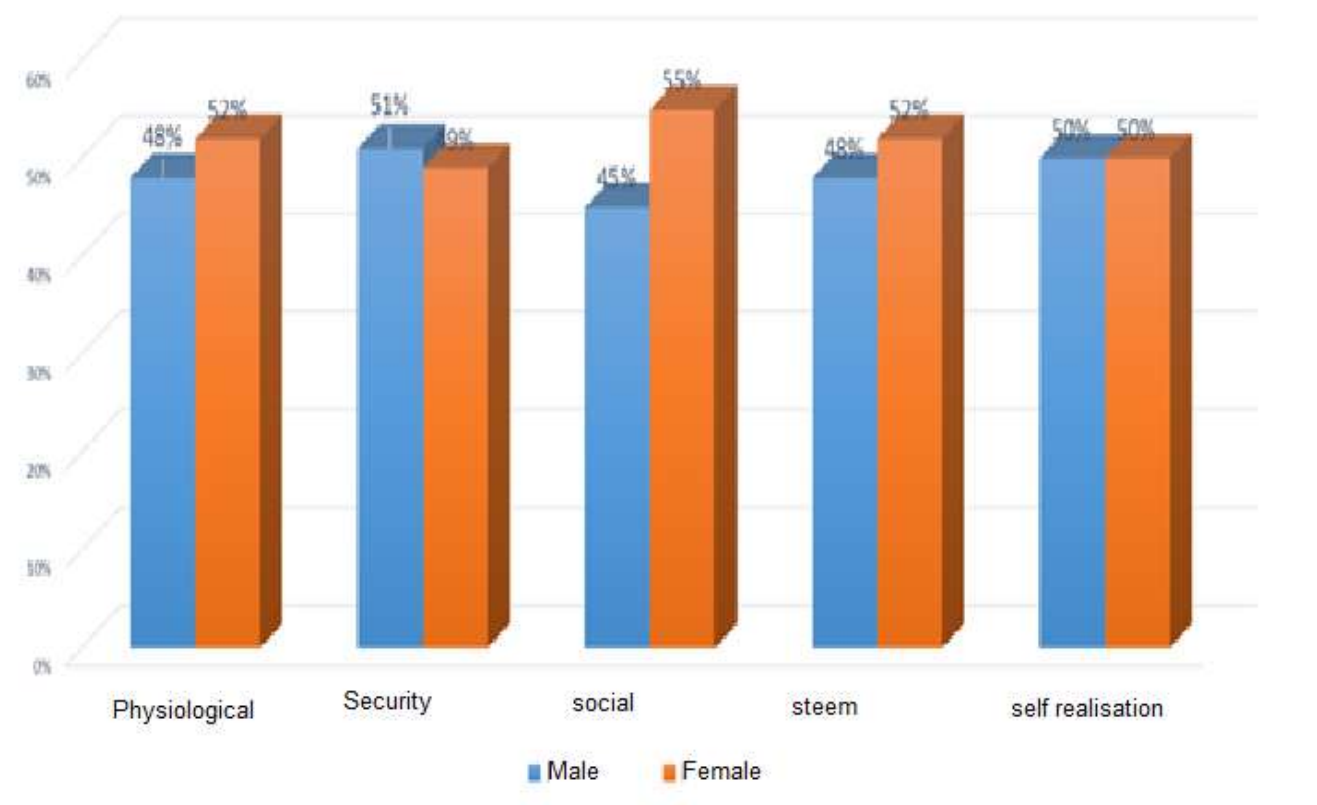

Source: Collegial work. Campeche. 2017

Analysis of Maslow's basic needs by levels of Hierarchy in higher level teachers

\section{Physiological needs:-}

The results obtained in the field of physiological needs, which reached $19.08 \%$ of the total of the five basic needs that Maslow proposes. That is to say those referred to those born with the person to maintain homeostasis (referring to survival ): such as the need to breathe, drink water (hydrate) and feed, sleep (rest) and eliminate body waste, as well as avoiding pain, maintaining body temperature and living in a warm or clothed environment, shows that higher level teachers are in search of a better living environment, this being their highest priority and the least is buying more food and clothing, see Figure 5. 


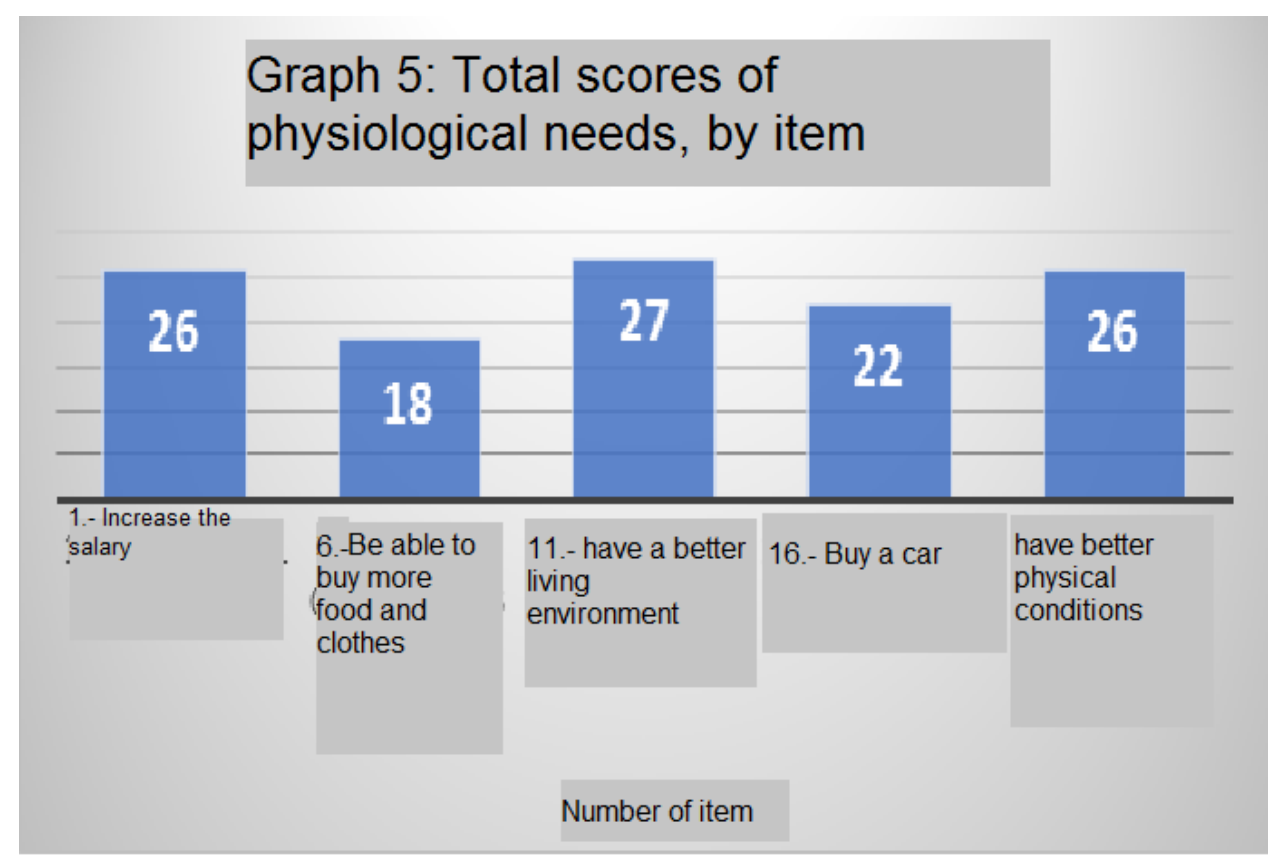

This behavior is explained by the Dynamics of the hierarchy of needs which indicates that when there is plenty of bread and the bellies are chronically full, other (higher) needs emerge and these, more than "the physiological hungers", dominate the organism. And when these in turn are satisfied, again new and higher needs emerge, and so on. This is what we want to communicate, Maslow points out, when we say that human needs are organized in a hierarchy of relative arrogance.

If the hunger is satisfied, it ceases to be important in the current dynamics of the individual. An implication of this thesis is that satisfaction becomes as important in the theory of motivation as deprivation, since it frees the organism from the domain of a relatively greater need. Physiological, allowing, therefore, the emergence of other more social purposes.

Maslow formulates a hierarchy of human needs in his theory and argues that as basic needs are met, human beings develop higher needs and desires. He points out that the physiological needs that are usually taken as the starting point for the theory of motivation are the so-called physiological drives. These physiological needs are the most powerful, the most powerful of all needs and that only unmet needs influence the behavior of all people, because the satisfied need does not generate any behavior.

As the person manages to control their basic needs, higher order needs gradually appear.

Regarding the measurement of the physiological need by gender, it was observed that women are more concerned about meeting these needs than men, a situation that is shown in Figure 6. 


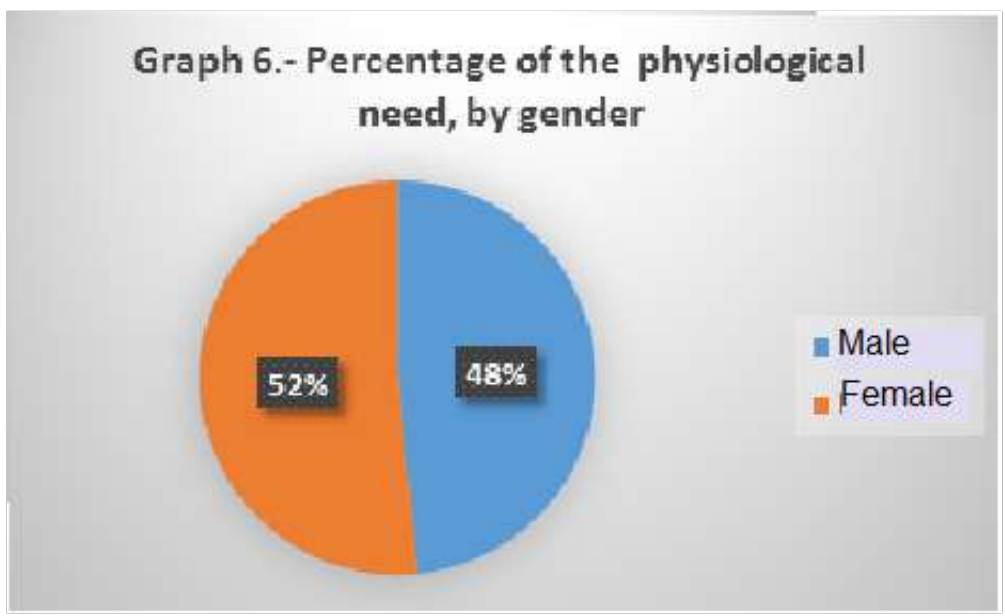

Source: Collegial work. Campeche. 2017

The second hierarchical level according to Maslow is safety, in the present study it was found that this level, together with the social need, occupies the second level of importance, reaching $20 \%$ of the total, for teachers at a higher level. This need was also measured by gender, the results show that teachers at a higher level have a prevalence in the male gender with $51 \%$, compared to $49 \%$ obtained for the female gender. This allows us to suppose some connection between the need for security and gender, given that men, due to their cultural condition, are associated with the role of men. See Graphic 7.

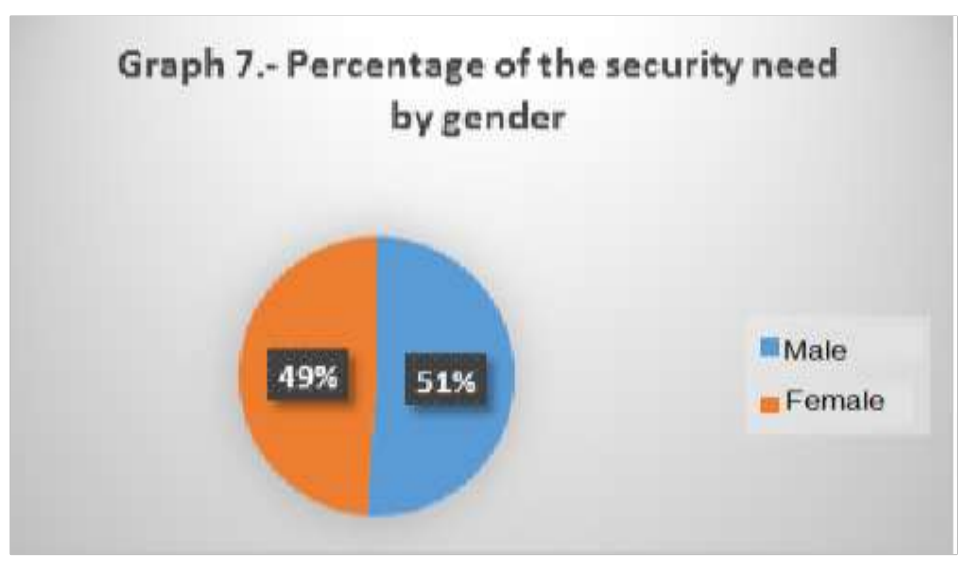

Source: Collegial work. Campeche. 2017

\section{Social Need:-}

At the social level, the second level of importance was assumed, as well as the security level, and by gender, the highest percentage was obtained by the female sex with 55\%, compared to the male gender, which represented $45 \%$, as it shows them. Graph 8 


\section{Graph 8.- percentage of the social need, by gender}

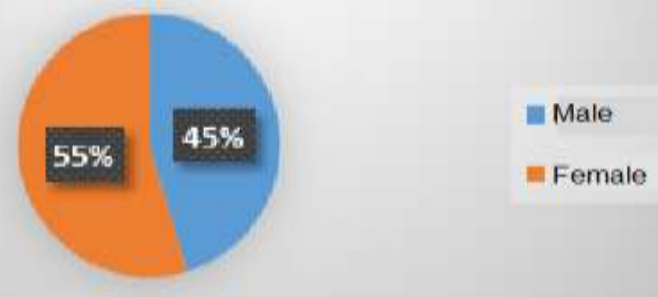

Source: Collegial work. Campeche. 2017

It should be noted that this result is explained because the human being by nature is gregarious, so in the different stages of life seek to be part of different groups; first the primary one called family, later the group of friends, school groups, labor group, sports group, among others.

The social need for items showed that higher education teachers valued more the search to "increase social skills", which reached the highest score (28), and the lowest was "receiving care from teachers and students", with 18 points, as shown in Figure 9.

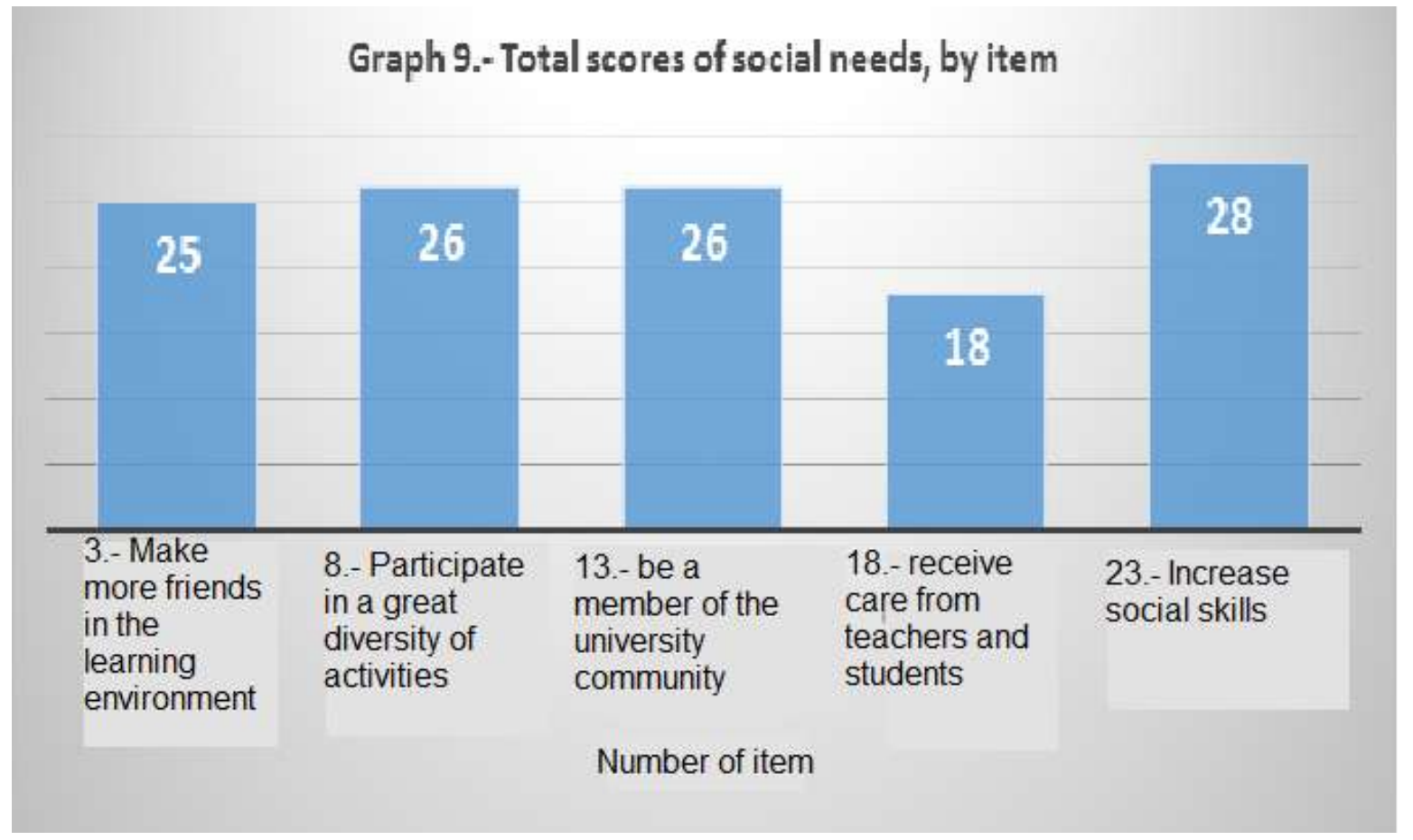

In the needs of affiliation and affection, Maslow, refers that are related to the affective development of the individual, such as the Association, participation and acceptance. (May, E., 2013)

\section{Need for Esteem:-}

The need for esteem occupies the third place of importance together with the needs, according to the hierarchy of needs of Maslow, the teachers of the superior level, have 19\% of search of the estimate of the total, being in men 48\% and women 52\%, as shown in Figure 10. 


\section{Graph 10.- ercentage of the steem needs,by gender}

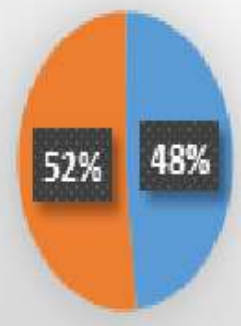

Male

Wemale

The results of the estimated needs in the items also showed interesting data being the following: both, men and women seek to execute their work with greater satisfaction. This being a constant search for professionals of higher level, in relation to the items of less value was found to achieve more self-acceptance and raise social status, since they consider it a necessity already covered in their work and professional life. See Chart 11.

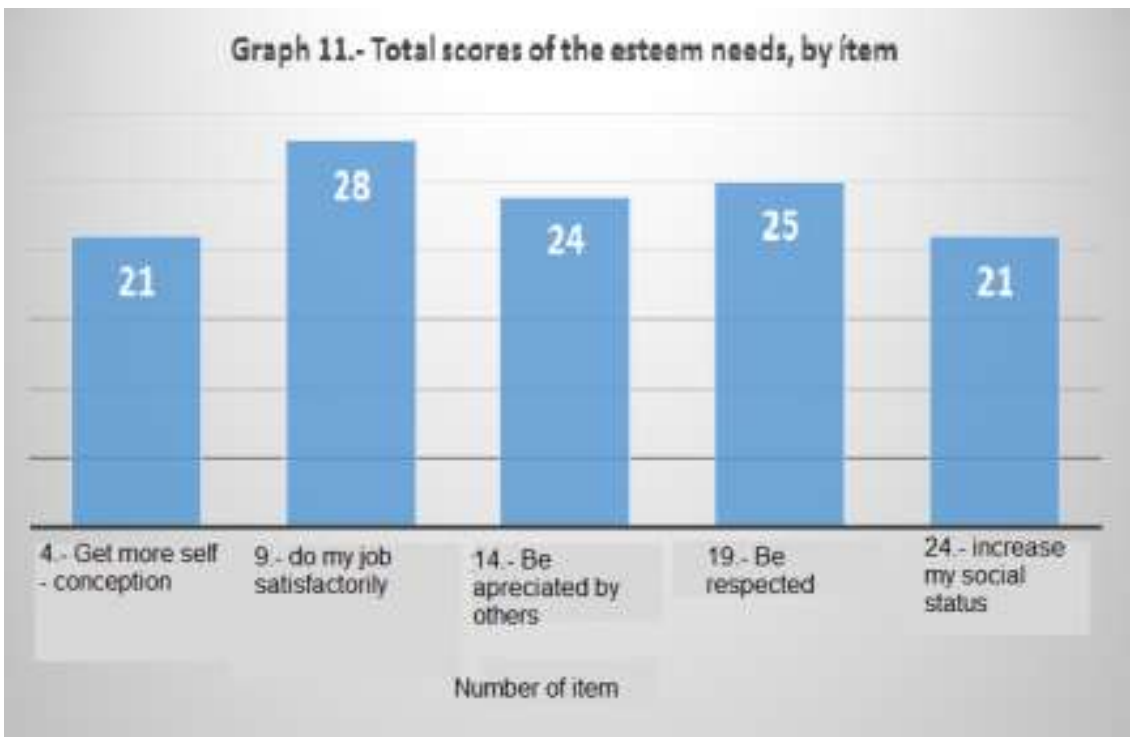

Source: Collegial work. Campeche. 2017

Maslow described two types of esteem needs, a high and a low.

- High esteem concerns the need for self-respect, and includes feelings such as trust, competence, mastery, achievement, independence and freedom.

- Low esteem concerns respect for other people: the need for attention, appreciation, recognition, reputation, status, dignity, fame, glory, and even dominance.

The decline in these needs is reflected in low self-esteem and the inferiority complex. Having satisfied this need supports the meaning of life and appreciation as an individual and professional, who can calmly step and advance the need for self-realization.

The need for self-esteem is the need for balance in the human being, given that it is the fundamental pillar for the individual to become the successful man he has dreamed of, or in a man destined to failure, which does not You can achieve anything by your own means. (May, E., 2013).

It can be concluded that at the level of Esteem, women have a greater search for esteem than men and that once the human being has achieved his social status, he does not seek to improve but to preserve it. 


\section{Self-realization needs:-}

The need for self-realization in the present study turned out to be the most important search for teachers at a higher level, occupying $22 \%$ of Maslow's total basic needs, where both genders were the most important to reach in life, as shows Graph 12.

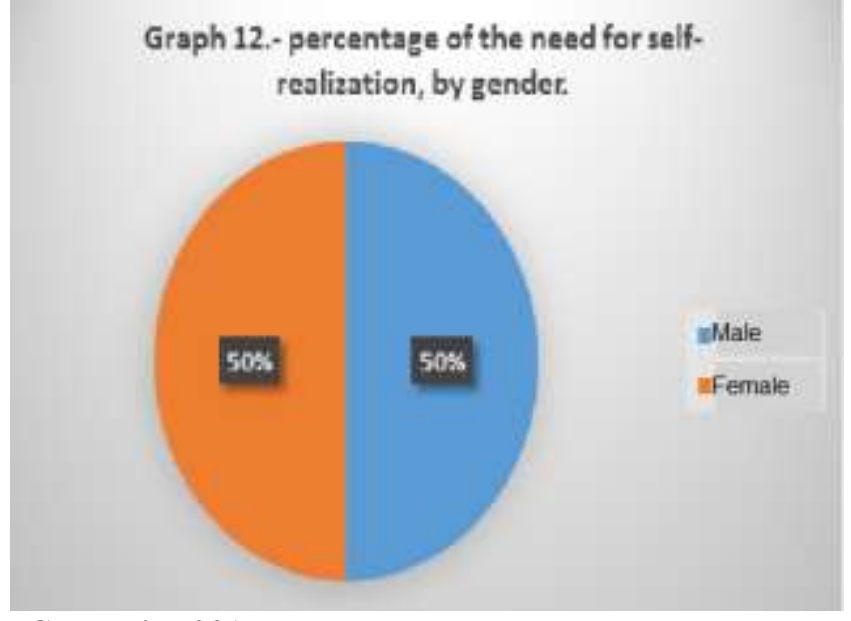

Source: Collegial work. Campeche. 2017

In this regard it is pertinent to note that Maslow considered self-realized a group of historical figures: Abraham Lincoln, Thomas Jefferson, Mahatma Gandhi, Albert Einstein, Eleanor Roosevelt, William James, among others, who met the following criteria:

I estimated that they were people:

- Focused on reality, they knew how to differentiate the false or fictitious from the real and genuine.

- Focused on the problems, which face the problems by virtue of their solutions.

- With a different perception of meanings and ends.

In their relationships with others, they were people:

- In need of privacy, feeling comfortable in this situation.

- Independent of the dominant culture and environment, based more on own experiences and judgments.

- Resistant to enculturation, since they were not susceptible to social pressure; They were nonconformist.

- With a non-hostile sense of humor, preferring jokes about themselves or the human condition.

- Good acceptance of themselves and others, as they were, not pretentious or artificial.

- Freshness in appreciation, creative, inventive and original.

- With a tendency to live experiences more intensely than the rest of humanity.

The ideal point of Maslow's theory would be one in which man feels "self-realized" but this is very rare, one could say that less than $1 \%$ of people reach full realization. (López, C. 2001)

\section{Conclusion:-}

In the study carried out with students of the Doctorate of Humanist Education, of the Humanist Institute of Higher Studies, in the city of San Francisco de Campeche, Mexico, in the month of May of 2017. The findings and the prevalences found were the following: the age of greater percentage is from 50 to 54 years. They are people who work in different disciplines of the social sciences. Single, with the same percentage in the masculine and feminine gender in the need of self-realization, nevertheless, it was observed that in the women, there is a greater social need than in men, who considered that the need for security is their greatest concern; In the item of the need for selfrealization, the highest percentage was "Enrich my life".

It was also relevant that the higher level teachers who attend the $\mathrm{PhD}$ in Humanistic Education, have satisfied their basic needs raised by Maslow: physiological, security, social, esteem and self-realization; finding that the latter is reported as the need with the highest average with $22 \%$, which is linked to the inclusion of these at an academic 
doctoral level. A final finding is that the female gender tends to seek more the satisfaction of basic needs compared to men, so we can intuit a link between basic needs and gender, since it was found that women report a higher percentage in the social need and men in need of security.

\section{Proposals:-}

The satisfaction of the basic needs of people to achieve a full life, implies having the capacity to hierarchize those needs. In the case of the present study where it was found that self-realization is the first important need, sought by higher-level teachers and the Of lesser importance is the search for esteem. It is proposed to carry out a mental health program in which aims to sensitize teachers that the search for a better salary is not more important than their physical and mental health.

\section{Suggestions Or Recommendations:-}

$\checkmark$ To develop actions of coexistence and recreation with the family and social groups with which there is affinity, to promote mental health.

$\checkmark$ Optimize the time delimiting the functions for each space: family, work, religious.

$\checkmark$ Prioritize projects, objectives and goals, without saturating the personal agenda.

\section{Bibliographic References:-}

1. Bauret, A., Rivera, M., García, M. et. al. (2009) Teoría y técnicas del humanismo. Recuperado de http://www.psicologia-online.com/articulos/2009/09/TeoriasTecnicasHumanismo.shtml

2. Rosal Cortés, R (2015). El crecimiento personal (o autorrealización): metas de las psicoterapias humanista. Anuario de psicología/ The UB Journal psychology, 34.

3. López, Carlos. (2001, julio11). La jerarquía de necesidades de Maslow. Recuperado de https://www.gestiopolis.com/jerarquia-necesidades-maslow/

4. Mayo, Elton, (2013). Teoría de las relaciones humanas. Recuperado de https://es.slideshare.net/leidysantosavila/abraham-maslow-y-elton-mayo 